\title{
Separation of Powers and the Application of the Political Question Doctrine in Uganda
}

\author{
Mtendeweka Mhango* \\ University of Witwatersrand, School of Law, Johannesburg, South Africa
}

\begin{abstract}
In Uganda, courts have considered and applied the political question doctrine since the 196os. This article examines the case law development and trends in the application of the political question doctrine theme in Ugandan jurisprudence. This article discusses the history of the political question doctrine in Uganda. It examines the case law developments and trends around the application of that doctrine in Uganda, and argues that the doctrine is undoubtedly part of the constitutional law of Uganda.
\end{abstract}

Keywords

Uganda; Political question doctrine; Matovu; Tinyefuza

\section{Introduction}

In Uganda, courts have considered and applied the political question doctrine since the 1960s. The political question doctrine is a function of the separation of powers doctrine and provides that there are certain questions of constitutional law that are constitutionally committed to the elected branches of government for resolution. ${ }^{1}$ As a result, such questions are non-justiciable and require the

*) E-mail: mtendeweka.mhango@wits.ac.za.Professor Mhango teaches pension and constitutional law at the University of Witwatersrand School of Law, South Africa, where he is also Acting Dean. His research focus is in pension and constitutional law.

1) See M. Redish, “Judicial Review and the 'Political Question' ", 79 Northwestern University Law Review (1984), 1031-1061; K. Breedon, 'Remedial Problems at the Intersection of the Political Question Doctrine, The Standing Doctrine and the Doctrine of Equitable Discretion', 34 Ohio Northern University Law Review (2008), 523-566 (explaining that the purpose of the political question doctrine is twofold. The first, rooted in the Constitution's separation of powers, is to ensure proper judicial restraint against exercising jurisdiction when doing so would require courts to assume responsibilities which are assigned to the political branches. The second is to ensure the legitimacy of the judiciary by protecting against issuing orders which courts cannot enforce); H. Wechsler, Principles, Politics, And Fundamental Law 11-14 (Cambridge University Press, Cambridge, 1961); K. Yoshino, 'Restrained Ambition in Constitutional Interpretation', 45 Willamette Law Review (2009), 557-564, at 559 (arguing that the political question doctrine is a doctrine of justiciability, noting that other such doctrines include standing, ripeness, mootness, and the bar on advisory opinions; that the justiciability doctrines underscore the idea that there can be rights without judicially enforceable remedies); and S. LaTourette, 'Global Climate: A Political Question?', 40 Rutgers Law Journal (2008), 219-284 (arguing that the political question doctrine is a function of the separation of powers). 
judiciary to abstain from deciding them if doing so would intrude upon the functions of the elected branches of government. ${ }^{2}$ The underlying theme is that such questions must find resolution in the political process. ${ }^{3}$ Like in Ghana and Nigeria, the development and application of the political question doctrine in Uganda has been influenced by legal developments in the United States. This article examines the case law development and trends in the application of the political question doctrine theme in Ugandan jurisprudence. This article discusses the history of the political question doctrine in Uganda. This article also discusses the case law developments and trends around the application of that doctrine in Uganda, and argues that the doctrine is undoubtedly part of the constitutional law of Uganda.

\section{Upholding Constitutional Making as a Political Question}

The Uganda High Court sitting as a Constitutional Court considered and adopted the political question doctrine in Uganda $v$ Commissioner of Prisons Ex Parte Matovu. ${ }^{4}$ In Matovu, the applicant, Michael Matovu, was arrested under the Deportation Act on 22 May 1966, and then released and detained again on 16 July 1966, under the Emergency Powers Act and the Emergency Powers (Detention) Regulations 1966 which had come into force after his initial arrest. Between 22 February and 15 April 1966, a series of events took place, including a declaration of a state of emergency in the region of Buganda. These events resulted in a unilateral suspension of the Constitution of 1962 , which had established a federal system of government between the Kingdom of Buganda and the Republic of Uganda, ${ }^{5}$ by the then Prime Minister Milton Obote. By this act, Obote had effectively taken over all powers of the government of Uganda by depriving the ceremonial President and Vice-President of Uganda, contrary to the Constitution of 1962, of their offices and vested their authorities in the Prime Minister and the Cabinet through the imposition of a new Constitution of 1966. Commentators refer to the Constitution of 1966, which was imposed on Uganda when Parliament adopted it on ${ }_{15}$ April $1966,{ }^{6}$ as the pigeon hole Constitution because it is said that the members of Parliament found copies of the Constitution in their pigeonholes for them to approve. ${ }^{7}$ The Commission of Inquiry into Violations of Human Rights describes these developments of 1966 as follows:

\footnotetext{
2) Ibid.

3) Ibid.

4) Uganda v. Commissioner of Prisons Ex Parte Matovu, [1966] EALR 514.

5) Eastern African Centre for Constitutional Development, Report of the Fact Finding Mission in Uganda on Constitutional Development (Eastern African Centre for Constitutional Development, Bukoto, 2002), 15.

6) Matovu, supra note 4 at 542 .

7) Eastern African Centre for Constitutional Development, supra note 5 .
} 
In February 1966 the Prime Minister suspended the 1962 Constitution. This was a unilateral action taken without consulting either Parliament or the people of Uganda. For a couple of months Uganda was literally governed without a Constitution. The 1966 Constitution was put in the pigeonholes of the Members of Parliament and they were asked to approve it even before reading it, and they did. In other words, this Parliament suddenly, and without consulting anybody, constituted themselves into a Constituent Assembly. They enacted and promulgated a Constitution whose contents they did not even know. ${ }^{8}$

According to one legal commentator the political arrangement under the Constitution of 1962 was an attempt to achieve the impossible and inevitably led to the coup of $1966 .{ }^{9}$

In Matovu, the applicant sought an order for his release. One of the issues that had to be determined by the Matovu Court was whether the Emergency Powers Act 1963 and the Emergency Powers (Detention) Regulations 1966 are utra vires the Constitution to the extent that the Act and Regulations enabled the President to take measures that may not be justifiable for purposes of dealing with the situation that existed during a state of emergency. Since there were two constitutions before the Matovu Court, being the Constitution of 1962 and Constitution of 1966, the Court on its own accord raised the question of the validity of the Constitution of 1966. When questioned by the Matovu Court, counsel for the applicant observed that he was in some doubt as to the validity in law of the Constitution of 1966. On the other hand, the government submitted that the Matovu Court had no jurisdiction to enquire into the validity of the Constitution because, among other reasons, the making of a Constitution is a political act and outside the scope of the functions of the Court.

According to the government's argument, since there are three arms of government, it was the duty of the legislature and the executive to decide the validity of the Constitution, the issue being a political one; that the duty of the Court was to accept that decision and merely interpret the Constitution as presented to it. It was also the government's submission that the members of the legislature, who passed the Constitution, did so as representatives of their constituencies to which they must account. Further, it pointed out that since judges were not elected but appointed and represented no specific constituencies to which to give account of their stewardship, the Matovu Court would be usurping the functions of the legislature if it undertook to enquire into and pronounce on the validity or otherwise of the Constitution of 1966. In support of this submission, the government referred the Court to United States Supreme Court cases in Luther, ${ }^{10}$ Marburyv. Madison, ${ }^{11}$

\footnotetext{
8) Ibid., at 16, citing Report of the Commission of Inquiry into Violations of Human Rights (1994).

9) Y. Ghai, 'Matovu's Case: Another Comment', 1 Eastern Africa Law Review (1968), 68.

10) Luther $v$ Borden, 48 U.S. 1 (1849) (held that controversies arising under the Guarantee clause of article four of the United States Constitution were political questions outside the purview of the court).

11) Marbury v. Madison, 5 U.S. (1 Cranch) 137 (1803).
} 
and Baker $v$ Carr, ${ }^{12}$ and the concept of the political question as discussed in these cases.

In addressing the government's submissions, the Matovu Court accepted that "the government's exposition of political question doctrine as elaborated in Luther cannot be faulted."13 Commentators consider Luther as a classical representation of the earliest application of the political question doctrine that was first developed in Marbury. ${ }^{14}$

In Luther, the United States Supreme Court had to determine whether it had the power to legitimize the popular dissolution of an entrenched state government. The plaintiff, Martin Luther, had been arrested after the declaration of martial law but before the enactment of the Rhode Island Constitution of 1843. The plaintiff was arrested by martial law troops after they had entered his home and damaged his property and harassed his elderly mother. ${ }^{15}$ The plaintiff later sued the martial law troops for trespass. The defendants, admitting an otherwise tortious breaking and entering, sought to justify their action on the ground that they were agents of the established lawful government of Rhode Island, which State was then under martial law to defend itself from active insurrection; that the plaintiff was engaged in that insurrection and that they entered his premises under orders to arrest the plaintiff. ${ }^{16}$

The case arose out of the political differences which agitated the people of Rhode Island between 1841 and 1842, and which had resulted in a situation wherein two groups laid competing claims to recognition as the lawful government. ${ }^{17}$ Plaintiff's lawsuit against the troops depended on which was the lawful government of Rhode Island at the time of his arrest, namely the government under the royal charter or the one under the People's Constitution. ${ }^{18}$ The lower court's refusal to hear argument on that issue, its charge to the jury that the earlier established or 'charter' government was lawful, and the verdict for the defendants, were affirmed upon appeal to the Supreme Court. ${ }^{19}$

\footnotetext{
12) Bakerv. Carr, 369 U.S. 186 (1962).

13) Matovu supra note 4 at 531.

14) Redish, supra note 1 at 1036; A. Savitzky, 'The Law of Democracy and the Two Luther v Bordens: A Counter History', 86 New York Law Review (2011), 2028-2070, at 2043 (-arguing that Luther expanded considerably the notion of a political question doctrine after Marbury). But see L. Henkin, 'Is There a 'Political Question' Doctrine?', 85 Yale Law Journal (1976) 597-625, at 608 (concluding that Luther did not establish a pure political question doctrine).

15) Luther $v$ Borden supra note 10 at 34. For a discussion of the political events during the Dorr rebellion, see G. Dennison, The Dorr War: Republicanism on Trial 1831-1867 (University Press of Kentucky, Lexington, KY, 1976); and M. Gentleman, The Door Rebellion: A Study in American Radicalism 1833-1849 (New York, NY, 1973).

16) Baker $v$ Carr supra note 12 at 218.

17) Ibid. See also, Luther v Borden supra note 10 at 34.

18) Luther $v$ Borden supra note 10 at 35 .

19) Ibid. See also discussion in Bakerv Carr supra note 12 at 217.
} 
Chief Justice Taney, who wrote the majority opinion in Luther, framed the issue in institutional terms and focused his analysis on the practical effects of deciding which sovereign was legitimate. ${ }^{20}$ He observed that if the Supreme Court could decide that the charter government was not legitimate, it could throw Rhode Island into legal chaos such as the invalidation of taxes and laws and possibly the nullification of its court decisions. ${ }^{21}$ Chief Justice Taney reasoned that "when the decision of this court might lead to such results, it becomes its duty to examine very carefully its own powers before it undertakes it to exercise jurisdiction." 22 Chief Justice Taney found that the power to decide which constitution or government was legitimate belonged to state officials, the Congress and the President but not in the federal courts. ${ }^{23}$ Further, he reasoned that Congress' decision under article IV of the United States Constitution to recognize a state government or its representatives is binding on every other department of government and could not be questioned in a judicial tribunal. ${ }^{24}$ In her reaction to the case, Professor Barkow is correct when she argues that Chief Justice Taney restated the classical theory of the political question doctrine and concluded that:

\footnotetext{
This tribunal, therefore, should be the last to overstep the boundaries which limit its own jurisdiction. And while it should always be ready to meet any question confided to it by the Constitution, it is equally its duty not to pass beyond its appropriate sphere of action, and to take care not to involve itself in discussions which properly belong to other forums. No one, we believe, has ever doubted this proposition..$^{25}$
}

The Matovu Court relied on Luther to arrive at its decision. According to the Court, the political question doctrine as articulated in Luther "is a sound doctrine," but was not applicable to the circumstances in Matovu. ${ }^{26}$ It reasoned that however useful and instructive the observations of the United States Supreme Court in the several matters discussed in that case maybe, the Ugandan government erred in relying on it as supporting the proposition that the validity of the Constitution

\footnotetext{
20) Savitzky, supra note 14 at 2039.

21) R. Barkow, 'More Supreme than Court? The Fall of the political Question Doctrine and the Rise of Judicial Supremacy', 102 Columbia Law Review (2002), 237-336, at 255; and Savitzky, supra note 9 at 2039-2040.

22) Lutherv Borden, supra note 10 at 39.

23) Luther $v$ Borden, supra note 10 at 39-43 (discussing the organs of government who have authority to resolve this dispute). See also Savitzky, supra note 9 at 2040.

24) Lutherv Borden, supra note 10 at 42 . See also Pacific States Telephone \& Telegraph Co. v. Oregon, 223 U.S. 118 (1912) (where an Oregon tax legislation was challenged on the basis that Oregon lacked a republican form of government because the Oregon constitution improperly permitted the people to legislate by initiative and referendum. The Court discussed how all sorts of problems would emerge if it were to conclude that Oregon lacked a republican form of government. It concluded that it would open the door for every citizen to challenge taxes or other government duties).

25) Luther $v$ Borden supra note 10 at 46 . See also Barkow, supra note 21 at $256-257$.

26) Matovu supra note 4 at $53^{1-533}$.
} 
of 1966 was a non-justiciable political question. ${ }^{27}$ Further, the Court found that Luther was irrelevant and distinguishable on the facts of Matovu.

Firstly, the Matovu Court observed that Luther was a contest between two rival groups as to which should control the government of Rhode Island. It argued that there was no such contest in Uganda, ${ }^{28}$ and observed that the government of Uganda is well established and has no rival. According to the Court, unlike in Luther, the question that was presented to it was not the legality of the government but the validity of the Constitution. While it is correct that Luther dealt with mainly the question of which government was legitimate, it is incorrect to characterize Luther as not examining the validity of the Constitution. To the contrary, the question of the validity of the Constitution was among the questions before the Luther Court. In his analysis of the Dorr Rebellion, which led to the Luther case, Professor Amar has observed that the charterists (one of the rival groups claiming to have established a lawful government) had submitted a Constitution, which had received the votes of less than one third of the adult males, less than half of the registered vote. ${ }^{29}$ Yet technically this became the Constitution of the State of Rhode Island, and the People's Constitution, which had been submitted by the other group, did not. ${ }^{30}$ According to Professor Amar, the valid Constitution received seven thousand votes; while as the People's Constitution nearly fourteen thousand. ${ }^{31}$

Chief Justice Taney considered the question of whether the People's Constitution as opposed to the charterists Constitution, which became the Constitution of Rhode Island, was valid, and found that the power to decide which Constitution was valid rested in state officials, the president and Congress. ${ }^{32}$ On this point, Savitzky has argued that Chief Justice Taney rejected the vote that had been casted on the People's Constitution as proof of its lawful adoption and declared:

Certainly it is no part of the judicial functions of any court of the United States to prescribe the qualification of voters in a State nor has it the right to determine what political privileges the citizens of a State are entitled to, unless there is an established constitution or law to govern its decision. ${ }^{33}$

As argued by Savitzky, the lack of established law or Constitution authorizing popular action was the very core of Chief Justice Taney's application of the political question doctrine. He observed that for Taney there was no rule by which a court

\footnotetext{
27) Ibid., at 533 .

28) Ibid.

29) A. Amar, 'The Central Meaning of Republican Government: Popular Sovereignty, Majority Rule, and The Denominator Problem' 65 University of Colorado Law Review (1994) 749-786, at 775 .

30) Ibid.

31) Ibid.

32) Luther v Borden, supra note 10 at 39-43. See also Savitzky, supra note 9 (arguing that Luther teaches that a court cannot competently choose a true Constitution).

33) Lutherv Borden, supra note 10 at 41. See also Savitzky supra note 102 at 2040.
} 
could determine the qualification of the voters upon the adoption of the proposed Constitution unless there was some previous law of the State to guide it. ${ }^{34}$

Secondly, the Matovu Court observed that Luther raised all sorts of political questions, including the right to vote and the qualification for such voters. Unlike in Matovu, there were two rival governors appointed in Luther and the rivalry between them produced a situation which was tantamount to a state of civil war. The Court observed that insurrection had in fact occurred in Rhode Island and war was levied upon the state. Further it, noted that Luther also involved the question as to whether the government was republican or not, which is a political question reserved for the Congress under Article IV of the United States Constitution. ${ }^{35}$ In the Court's view, these circumstances were not present in Matovu.

While the Matovu Court acknowledged that Luther involved political questions such as the right to vote, it fails to recognize that this political question was considered in the context of deciding the validity of the two rival constitutions in Rhode Island. Further, while the political instability in Rhode Island at the time when Luther was decided may not be equated to that which prevailed in Uganda at the time of Matovu, it is misleading for the Matovu Court to paint a rosy picture of the political situation in Uganda at the time. The fact is there was a considerable amount of political instability in Uganda that was predicated upon Matovu and surrounding political events, which eventually led to the coup d'état of 1971 that brought General Idi Amin to power. ${ }^{36}$

It is surprising that despite finding that Luther was distinguishable from Matovu, the Court reached a conclusion which is in accord with Chief Justice Taney's main considerations in deciding Luther ${ }^{37}$ The Court held that any decision by the judiciary as to the legality of the government could be far reaching, disastrous and wrong because the question was a political one to be resolved by the executive and legislature, which were accountable to the constituencies. ${ }^{38}$ However, unlike

34) Luther $v$ Borden, supra note 10 at 41; and Savitzky, supra note 102 at 2040.

35) See Luther v Borden, supra note 10 at 42. Barkow, supra note 21 at 256. The Matovu Court also discussed Bakerv Carr in ways that is not clear whether they considered it controlling in Matovu or not. Supra note 4 at $533-535$.

36) Following Amin's ascendancy to power Uganda remained relatively unstable and erupted into a civil war between 1981 to 1986 . It was only in 1995 , when Uganda adopted a -democratic Constitution. It could be argued that the period between 1966 to 1986 can best be characterized as a period of political instability in Uganda. For some discussion about the political history of Uganda, See H. Ingrams, Uganda: A Crisis of Nationshood (Her Majesty's Stationery Office, London, 196o); P. Mutibwa, Uganda Since Independence: A Story OfUnfulfilled Hope (World African Press, Kampala, 1992); and J. Okuku, Ethnicity, State Power and The Democratisation Process in Uganda (Nordic Africa Institute, Uppsala, 2002).

37) Luther $v$ Borden, supra note 10 at 38-39 (noting that "if the court could decide that the charter government was not lawful, it could throw Rhode Island into legal chaos-convictions would be reversed, compensation revoked and legislation abrogated").

38) Matovu, supra note 4 at 515 and 540 . See also, Barkow, supra note 21 at 255 (observing that Chief Justice Taney was motivated by practical concerns such as the potential legal chaos that would ensure if the court had decided one way or another); Savitzky, supra note 14 (noting that Luther decided against determining which was the legitimate government because this would Rhode Island into legal chaos). Professor 
Luther, the Matovu Court held that a decision on the validity of the Constitution was within the Court's competence. ${ }^{39}$ It found that the Constitution of 1966 was valid for a number of reasons including the fact that it had been accepted by the people of Uganda and the international community, and had been firmly established and implemented throughout the country without opposition. ${ }^{40}$ Hence, the Court felt it could not reverse this political reality. There is probably another practical consideration that led the Court to legitimate the Constitution of 1966 and that is the fear of rendering all past acts and taxes open to legal challenges, including the legitimacy of the judges that had been appointed by the Prime Minister Obote under the impugned Constitution.

It is possible to criticize Matovu for misconstruing and misapplying Luther. I submit that Luther was controlling on Matovu because it teaches that the act of constitutional formation is the province of the people alone as popular sovereignty. As Justice Woodbury observed, in his concurring opinion in Luther, "our power begins after theirs end." ${ }^{\prime 1}$ In this regard, the government of Uganda correctly relied on Luther. While Matovu has been criticized by some commentators, ${ }^{42}$ it is still good law in Uganda and has been cited with approval by judges in Uganda ${ }^{43}$ and elsewhere. ${ }^{44}$ Since Matovu, the political question doctrine has been the subject of consideration and application by the Uganda Court of Appeal in Andrew Kayira v Edward Rugumayo \& Others ${ }^{45}$ where the Court relying on Matovu ruled that the removal Professor Lule from the office of President of Uganda was a political question not reviewable in the courts of law but reserved to the political organs of the state. Perhaps the most cardinal application of the political question doctrine, in the context of the post-1995 Constitution of Uganda, was by Supreme Court of Uganda in Attorney Generalv Major General David Tinyefuza. ${ }^{46}$

\footnotetext{
Weinberg has argued that the duty of courts does not evaporate because there are obstacles to enforcement or threats of crisis or chaos, and yet Matovu and Luther alike seemed to have been decided on this basis. See also, L. Weinberg, 'Political Questions and the Guarantee Clause', 65 University of Colorado Law Review (1994), 889-947, at 905 .

39) Ibid.

40) Matovu, supra note 1 at 539.

41) Luther $v$ Borden, supra note 4 at 52; and Savitzky, supra note 14 at 2041.

42) See, M. Kirya, The Independence and Accountability of the Judiciary in Uganda: Opportunities and Challenges (2009) available online at http://www.kituochakatiba.org/index.php?option=com_ docman\&task=doc_details\&gid=369\&Itemid=36(criticizing Matovu)(last accessed 12 May 2013); C. Kirkby, Exorcising Matovu's Ghost: Legal Positivism, Pluralism and Ideology in Uganda's Appellate Courts, 12-21 (LLM Thesis, McGill University, Montreal, QC, 2007); N. Mkwentla, The Legal Effect of a Coup D'Etat on Traditional Constitutional Concepts (LLM Thesis, Rhodes University, Grahamstown, 2001)(discussing Matovu and other cases).

43) Attorney General v. Major General David Tinyefuza, Const. Appeal No.1 of 1997 (S.C), (unreported); Andrew Kayira v Edward Rugumayo \& Others, Constitutional Case no 1 (1979); Centre of Health Human Rights v Attorney-General, Constitutional Petition No 16 (2011).

44) See Madzimbamuto v Larder Burke (1966) 1 AC 645; R. v. Ndhlovu 1968 (4) SA 515.

45) Andrew Kayira v Edward Rugumayo \& Others, supra note 148.

46) Attorney Generalv. Major General David Tinyefuza, Const. Appeal No.1 of 1997 (S.C), (unreported).
} 


\section{Upholding Military Matters As Political Questions}

The case of Tinyefuza arose when on 29 November 1996 General Tinyefuza gave evidence before the Parliamentary Sessional Committee (Sessional Committee) on Defence and Internal Affairs about the insurgency in North Uganda. In his testimony, General Tinyefuza made a harsh attack on the Uganda Peoples' Defence Force regarding its conduct generally and in -particular, it's handling of the insurgency in North Uganda. ${ }^{47}$ General Tinyefuza then learned from media reports that the military authorities thought his evidence before the Sessional Committee "did not conform with the military line" and that he should resign from the army and appear before the High Command. ${ }^{48}$ General Tinyefuza did not consider himself a member of the army at the time he addressed the Committee, but to clear the air he resigned by a letter sent to the President. ${ }^{49} \mathrm{He}$ received a response from the Minister of Defence rejecting his resignation on the basis that it did not comply with the National Resistance Army (Conditions of Service)(Officers) Regulations $1993 \cdot{ }^{50}$ General Tinyefuza perceived these events as exposing him to an atmosphere of fear and felt that his rights were about to be infringed.

As a consequence, General Tinyefuza petitioned the Constitutional Court seeking a declaration that the threats to punish him for his testimony before the Sessional Committee would be in conflict with Article 87 of the Constitution; that the rejection of the resignation letter was unconstitutional and that the army regulations were no longer applicable to him because - at the time of his testimony - he had been appointed to a post in the public service. ${ }^{51}$ The Constitutional Court ruled in favor of General Tinyefuza and the Attorney General appealed to the Supreme Court. ${ }^{52}$ The Supreme Court in a five ${ }^{53}$ to two ${ }^{54}$ decision reserved the Constitutional Court.

In his opinion in favor of the majority view, Justice Kanyeihamba remarked at the outset that in order to dispose of this appeal according to the principles of the Constitution and laws of Uganda, it was essential for him to make some preliminary

\footnotetext{
47) See Major General David Tinyefuza v Attorney Genera [1997] UGCC 3 (Justice Manyido opinion).

48) Attorney General v. Major General David Tinyefuza, Const. Appeal No.1 of 1997 (S.C) (Justice Wambuzi opinion), at 2.

49) Ibid.

50) After submitting his resignation, there were media reports quoting the President saying that General Tinyefuza would have to sort out his problems with the army before he is allowed to resign. Criticisms against General Tinyefuza from other senior army officials were also reported in the media. See Major General David Tinyefuza v Attorney Genera [1997] UGCC 3 (Justice Manyido opinion).

51) Ibid.

52) For a discussion of the Court of Appeal decision see, Justice Constance Byamugisha, Administering Justice Without Undue Regard to the Technicalities, (December 2003) A paper presented to Green Watch Uganda. See also Paul Semogerere v Attorney-General, Constitutional Appeal No 1 (2002); and R. Ellet, Emerging Judical Power in Transitional Democracies: Malawi, Tanzania and Uganda (ProQuest, Ann Arbor, MI, 2008), pp. 407-498.

53) Justices Kanyeihamba, Wambuzi, Tsetooko, Karokora, and Kekonyo.

54) Justices Mulenga and Oder.
} 
observations which he said ought to guide a court in adjudicating constitutional matters of this kind and others. ${ }^{55}$ Justice Kanyeihamba began by examining the political question doctrine as applied in the United States and as developed by the courts in Uganda. ${ }^{56} \mathrm{He}$ observed that the general rule is that courts have no jurisdiction over matters which are within the constitutional and legal powers of the legislative or the executive. ${ }^{57}$ Kanyeihamba went on to observe that even in those cases where courts feel obliged to intervene and review legislative or executive acts when challenged on the basis that the rights of an individual are infringed, they do so sparingly and with great reluctance.$^{58}$ Further, he re-affirmed the endorsement in Matovu of the political question doctrine.$^{59}$ Constitutional commentators agree with Justice Kanyeihamba's approach to constitutional adjudication, arguing that 'the political question doctrine requires the judiciary to decide as a threshold matter in all cases whether the question before it has been assigned by the Constitution to another co-ordinate branch of government. ${ }^{\prime 60}$

Before addressing the merits, Justice Kanyeihamba highlighted some of the areas which, in his view, would be appropriate to apply the political question doctrine in Uganda. ${ }^{61} \mathrm{He}$ noted that among them is whether or not courts should demand proof of whether a statute of the legislature was passed properly or not; the conduct of foreign relations; ${ }^{62}$ and the question of when to declare and terminate wars and insurgencies. ${ }^{63}$ Most commentators acquiesce to Justice Kanyeihamba's

\footnotetext{
55) Tinyefuza, supra note 43 , at 3 .

56) Ibid., at 11.

57) Ibid.

58) Ibid.

59) Ibid., at 12.
}

60) Barkow, supra note 21 at 243-244; M.E. Nixon-Graf, 'A Gathering Storm: Climate Change as Common Nuisance or Political Question?', 19 New York University Environmental Law Journal (2012), 353-379 (discussing that the political question doctrine requires courts to make a threshold determination whether a claim is properly within the judicial branch of government); M.D. Gouin, 'United States v AlvarezMachain: Waltzing with the Political Question Doctrine', 26 Connecticut Law Review (1994), 759-781 (arguing in favour of the applying the political question doctrine in foreign affairs cases); R. Price, 'Banishing the Specter of Judicial Foreign Policymaking: A Competence-Based Approach to the Political Question Doctrine', 38 NYUJournal of International Law \& Politics (2006), 323-354, at 331 (advocating for a reformulated political question doctrine so that it is used to more carefully distinguish between those cases that raise separation of powers concerns and should therefore be dismissed, and those which do not.); and K. Breedon, supra note 1 (characterising the political question as a self-imposed restraint mechanism on the judiciary, which requires courts to dismiss a case as nonjusticiable if deciding the matter in dispute would encroach upon the functions of the electoral branches of government).

61) Tinyefuza, supra note 43 at 12.

62) B. Free, 'Waiting Does v Exxon Mobole Corp: Advocating the Cautious Use of Executive Opinions in Alien Tort Claims Act Litigation', 12 Pacific Rim Law \& Policy Journal (2003), 467-498; Gouin, supra note 6o at 763-781; F.W. Scharpf, 'Judicial Review and the Political Question: A Functional Analysis, 75 Yale Law Journal (1966), 517-597, at 567, 583-584; J. Nzelibe, 'The Uniqueness of Foreign Affairs', 89 Iowa Law Review (2004), 941-1009; Oetjen v. Central Leather Co., 246 U.S. 297 (1918) (applying the political question doctrine to the conduct of the foreign affairs); United States v. Belmont, 301 U.S. 324 (1937) (noting that the executive branch has exclusive competence in foreign affairs).

63) Tinyefuza, supra note 43 at 12. In the United States, courts typically take the same view in cases involving military matters. See Crockett v. Reagan, 720 F.2d 1355 (D.C. Cir. 1983), cert. denied, 467 U.S. 1251 (1984) 
characterization of areas which are most appropriate for the application of the political question doctrine. ${ }^{64}$ Based on common law authorities, Justice Kanyeihamba was convinced that courts should avoid adjudicating upon these kinds of questions unless in very clear cases of violation or threatened violation of individual liberty are shown. ${ }^{65}$ Justice Kanyeihamba added that the reluctance of courts to enter into the arena reserved by the Constitution to the other arms of government reaches its zenith when it comes to the exercise and control of powers relating to the armed forces their -structure, organization, deployment and operations. ${ }^{66}$ In his view, the accepted principle is that courts would not substitute their own views of what is in the public interest in these matters particularly when the other co-ordinate arms of government are acting within the authority granted to them by the Constitution. ${ }^{67}$

(finding suit regarding U.S. military activities in El Salvador raised nonjusticiable political question); Lowryv. Reagan, 676 F. Supp. 333 (D.D.C. 1987) (finding suit to compel presidential compliance with War Powers Resolution raised nonjusticiable political questions). Chicago \& S. Air Lines v. Waterman S.S. Corp., 333 U.S. 103 (1948); Johnson v. Eisentrager, 339 U.S. 763, 789 (1950) (holding that "certainly it is not the function of the Judiciary to entertain private litigation - even by a citizen - which challenges the legality, the wisdom, or the propriety of the Commander-in-Chief in sending our armed forces abroad or to any particular region."); United States v. Curtiss-Wright Export Corp., 299 U.S. 304, 319 (1936) (holding that in this vast external realm, with its important, complicated, delicate and manifold problems, the President alone has the power to speak as a representative of the nation).

64) Gouin, supra note 6o; C.R. Chase, "The Political Question Doctrine: Preventing the Challenge of US Foreign Policy in 767 Third Avenue Associates v Consulate General', 50 Catholic University Law Review (2001), 1045-1080, at 1055; L. Wishik, 'Separation of Powers and Adjudication of Human Rights Claims Under Alien Tort Claims Act-Hanoch-Tel-Oren v Libyan Arab Republic, 726 F.2D 774 (D.C.CIR.1984), Cert. Denied, 105 S.CT. 1354 (1985)', 6o Washington Law Review (1985), 697-720; H. Wechsler, Principles, Politics and Fundamental Law (Havard University Press, Cambridge, MA, 1961), at 11-14.

65) Tinyefuza, supra note 43 at 12.

66) Ibid. Under United States law, the greater the degree of control by the military the more likely the courts are going to find that challenges involving the military or private military contractors present nonjusticiable political questions. See Whitaker v Kellog Brown \& Root, Inc, 444 F. Supp. 2d 1277, 1281 (2006) (holding private military contractor was subject to military's orders, regulations, and convoy plan, rendering suit against the private military contractor arising out of convoy accident nonjusticiable). B. Davidson, 'Note, Liability on the Battlefield: Adjudicating Tort Suits Brought by Soldiers Against Military Contractors', 37 Public Contract Law Journal (2008) 822-834; J.H.L. Perez-Montes, 'Comment, Justiciability in Modern War Zones: Is the Political Question Doctrine a Viable Bar to Tort Claims Against Private Military Contractors?', 83 Tulane Law Review (2008), 219-254, at 246.

67) Most judges agree with this view and have similarly held that the political branches are better placed than the judiciary to appreciate what is to the public benefit. Chief Justice Gubbay writing for a unanimous Supreme Court of Zimbabwe in the landmark case of Nyambirai v National Social Security Authority 1996 (1) SA 636 (ZS) explained it convincingly when he upheld a legislative policy to compel employees and employers to save for their retirement and said: "I do not doubt that because of their superior knowledge and experience of society and its needs, and a familiarity with local conditions, national authorities are, in principle, better placed than the Judiciary to appreciate what is to the public benefit. In implementing social and economic policies, a government's assessment as to whether a particular service or programme it intends to establish will promote the interest of the public is to be respected by the courts. They will not intrude but will allow a wide margin of appreciation, unless convinced that the assessment is manifestly without reasonable foundation. The Minister has proclaimed that the Pensions and Other Benefits Scheme provides a service in the public interest. That is an assessment which this Court should respect" (at 644). See also Apostolou \& others v The Republic of Cyprus (1985) LRC (Const) 851 (rejecting the 
Justice Kanyeihamba's reasoning is that that since military matters are within the exclusive jurisdiction of both executive and legislature, it is not for the courts to consider whether the discretion of the executive has been exercised properly, if at all. ${ }^{68} \mathrm{In}$ his view, it is parliament which has the authority to bring the executive to account in these military matters. ${ }^{69}$ To support Justice Kanyeihamba's view, the United States Court of Appeal in Schneider v Kissinger makes an important pronouncement that 'the lack of judicial authority to oversee the conduct of the executive branch in political matters does not leave executive power unchecked because political branches exercise checks and balances on each other in the area of political questions. ${ }^{.70}$ Some commentators agree with these judicial sentiments. For instance, Ibrahim Imam writing with others has made an important suggestion that "we should not be overly concerned that the political question doctrine deprives the courts of enforcement power over certain constitutional provisions because the Constitution and electoral process provides an appropriate substitute."71 Thus, Justice Kanyeihamba cannot be faulted for pointing out that Parliament is the appropriate organ of government to check the executive on military questions, and that in the context of the political question doctrine, this is a sufficient constitutional check on executive power. ${ }^{72}$

Justice Kanyeihamba then reflected on the principle of separation powers under the Constitution of Uganda and was very clear that in Uganda, as in the United States, courts are not the only actors on the constitutional stage. ${ }^{73}$ In my view, he correctly observed that the Constitution provides that the constitutional platform is to be shared between the three arms of government, being the executive, judicial and legislative arms; that courts need to bear in mind the judgments of other repositories of constitutional power concerning the scope of their authority and the necessity for each to keep within its powers including the courts

argument that the government had no authority to compel a self-employed individual to pay contributions to the social insurance fund established under the Social Insurance Law of 1980; Sechelev Public Officers Defined Contribution Pension Fund and Others [2010] LSHC 94 (upholding a compulsory civil service pension fund in Lesotho); Steward Machine Company v Davis 301 US 548 (1937)(upholding the provisions of the United States Social Security Act of 1935); Schweiker v Wilson, 450 US 221, 230 (1981)(reasoning that unless a statute employs a classification that is inherently invidious or that impinges on fundamental rights, this Court properly exercises only a limited review power over Congress, the appropriate representative body through which the public makes democratic choices among alternative solutions to social and economic problems).

68) For a similar reasoning see Corrie v. Caterpillar, Inc., 503 F., 3 d 974 (9th Cir. 2007) (declining to intrude into the government decision to grant military assistance to Israel because this question was committed under the Constitution to the legislative and executive branches).

69) Tinyefuza, supra note 43 at 12.

70) Schneider v Kissinger 412 F.3d 190, 200 (2005).

71) I. Imam, A.O. Sambo, W. Egbewole and A.B. Abdulkadir, 'Judicial Activism and Intervention in the Doctrine of Political Questions in Nigeria: An Analytical Exposition' 1 African Journal of Law and Criminology (2011), 50-69, at 51, citing Obiv INEC (2007) 9 MJSC 1.

72) Olson v Morrison, 487 US 654 (1988)(Scalia dissenting)(arguing that another significant check is that people will replace those in the political branches who are guilty of abuse of power).

73) Tinyefuza, supra note 43 at 13. 
themselves. Professor Tribe has agreeably observed that 'so long as the manner in which the Constitution is to be interpreted remains open to question, the meaning of the Constitution is subject to legitimate dispute, and the judiciary is not alone in its responsibility to interpret. ${ }^{74}$

Instead, Justice Kanyeihamba pronounced that the principle of separation of powers demands that unless there is the clearest of cases calling for intervention for purposes of determining constitutionality of action or the protection of the liberty which is presently threatened, the courts must refrain from entering arenas not assigned to them either by the Constitution or laws of Uganda. Moreover, he pronounced that it is necessary in a democracy that courts refrain from entering into areas of disputes best suited for resolution by other government agents. In their discussion of the political question doctrine in Canada, Cowper and Sossin have similarly observed and argued that "based on the principle of separation of powers, the political question doctrine limits judicial power in a number of circumstances where the other branches of government have a stronger claim to decide the issue raised." ${ }^{25}$ I think it is clear that Kanyeihamba's pronouncement reflects the idea that the executive and legislature have a stronger claim to decide military questions that emerged in this case.

It is understandable from Justice Kanyeihamba's examination above that in Uganda, as it is Ghana and the United States, the political question doctrine is recognized as originating from the principle of separation of powers. Moreover, it is also understandable that there are potential limits on the application of the political question doctrine; that is to say it may not apply in cases of clear constitutional violations or abuse of power. Justice Kanyeihamba's views in this regard are similar to those of Justice Kpegah of the Supreme Court of Ghana. The two justices hold similar views on the proper equilibrium of powers among the three arms of government insisting on the notion that each arm of government enjoys equal constitutional powers to interpret and enforce a Constitution. ${ }^{76}$

74) L.H. Tribe, American Constitutional Law (Foundation Press, New York, NY, 1988) at 34-35. See also United States $v$ Butler, 297 U.S. 1, 87 (1936) (Justice Stone dissenting) (arguing that courts are not the only agency of government that must be assumed to have the capacity to govern); J.P. Mulhern, 'In Defense of the Political Question Doctrine', 137 University of Pennsylvania Law Review (1988), 97-176, at 126 (arguing that there is no obvious reason why a court's assertion of judicial power should be any more authoritative than a president's assertion of executive power. Both are part of our constitutional tradition and there is no apparent way to establish any priority between them. Courts share responsibility for interpreting the Constitution with the political branches); and L. Seidman, 'Secret Life of the Political Question Doctrine' 37 John Marshall Law Review (2003), 441-480, at 442 (arguing that Constitution vests in the political branches final interpretive authority as to the meaning of some constitutional provisions; that in relation to those provisions the political branches self-monitor).

75) G. Cowper and L. Sossin, 'Does Canada Need A Political Questions Doctrine?', 16 Supreme Court Law Review (2002), 334-372, at 345 .

76) See Muhern, supra note 74; Cowper and Sossin, supra note 75; Tribe, supra note 74; and Barkow, supra note 21 at 239 (arguing that the constitutional structure vests some interpretive authority with the political branches); and Seidman, supra note 74 at 444 (arguing that political branches have final interpretive authority as to the meaning of the Constitution). 
Tinyefuza is not the most recent application of the political question doctrine in Uganda. As early as March 2012, the Constitutional Court dismissed a case on the basis of this doctrine.

\section{Upholding Healthcare Matters As Political Questions}

The Constitutional Court of Uganda recently applied Tinyefuza to dismiss a constitutional petition in Centre of Health Human Rights $v$ Attorney-General ${ }^{77}$ (herein as the Maternal Health Case), a case challenging government action or inaction on the basis of the political question doctrine as articulated in Tinyefuza. In Maternal Health Case, the plaintiffs petitioned the Constitutional Court in terms of sections 137(3) and 45 of the Constitution challenging the failure of government to provide basic maternal commodities in government health facilities. The plaintiffs sought a declaration that acts or omission of government, which have led to high maternal deaths in Uganda, were inconsistent with the constitutional right to life and health.

At the start of the proceedings, the government raised a preliminary objection to the Constitutional Court's jurisdiction to hear the matter on the basis that the political question doctrine prohibits the judiciary from hearing cases of this nature. ${ }^{78}$ At least to some extent the government's preliminary objection in the Maternal Health Case is consistent with Justice Kanyeihamba's pronouncement in Tinyefuza "that courts have no jurisdiction over matters which are within the constitutional and legal powers of the political branches of government." What is more, the government can be read to be of the same mind with Professor Barkow's thinking that 'in all constitutional cases the primary question must be whether the question before a court has been committed to another branch of government. ${ }^{79}$

Relying on Tinyefuza and other foreign authorities, the government argued that the way the petition was framed required the court to make a judicial decision involving political questions, which the court had to determine at the outset whether it had jurisdiction to determine those questions. Further, it argued that in adjudicating such mattes, the Constitutional Court would in effect be interfering with political discretion which by law is a preserve of the executive and legislature. Further, the government's view was that the Constitutional Court should not deal directly with questions that the Constitution has made the sole responsibility of other branches of government; that for the Constitutional Court to determine the issues in the petition, it would be required to review all the policies of the entire health sector and make findings on them, and that the implementation of these policies was the sole preserve of the executive and legislature. To further

\footnotetext{
77) Centre of Health Human Rights v Attorney-General, Constitutional Petition No 16 of 2011.

78) Citing Attorney General v. Major General David Tinyefuza, Baker $v$ Carr, supra; and $R v$ Cambridge Health Authority ex PB [1995] 2 ALL ER 129.

79) Barkow, supra note 21 at 244.
} 
substantiate its claims, the government submitted an affidavit by the Principal Secretary of the Ministry of Health, which outlined the efforts and strategies undertaken by the government to improve maternal health services and ensure high standards in the health sector. It then cited sections $111(2)^{80}$ and ${ }_{17} 6(2)(\mathrm{e})^{81}$ of the Constitution that it claimed preserved the right of the executive and the legislature to formulate, review and implement policies and allocate resources.

In dismissing the petition, the Constitutional Court endorsed the political question doctrine as pronounced by the Supreme Court in Tinyefuza. ${ }^{82}$ While the Court was correct in stating that that doctrine had been adopted by the Supreme Court in Tinyefuza, it is important to point out that the Constitutional Court first adopted the political question doctrine in Matovu and subsequently applied it in Andrew Kayira $v$ Edward Rugumayo. ${ }^{83}$ In fact, in Tinyefuza Justice Kanyeihamba acknowledged that Matovu had adopted the political question doctrine as a sound principle to be applied in Uganda. Perhaps, one of the significance of highlighting Tinyefuza's adoption of the political question doctrine is that Tinyefuza was the first case that applied the political question doctrine after the 1995 Constitution. Prior to Tinyefuza, it remained uncertain whether the political question doctrine was applicable in Uganda under the 1995 Constitution.

In justifying the application of the political question doctrine in the Maternal Health Case, the Constitutional Court reasoned that the Constitution clearly stipulated the different roles assigned to each of the three organs of government. According to the Constitutional Court, this implied that the autonomy of each organ of government must be immune from undue intrusion from the others. In as much as it may be correct that the government had not allocated sufficient resources to the health sectors, the Court reasoned that the duty to determine such matters was the preserve of the executive and no other organ of government. For this reason, the Constitutional Court pronounced that it is bound to leave certain constitutional questions of a political nature to the executive and legislature to determine. The Constitutional Court justified its reluctance in adjudicating the issues in the petition arguing that in doing so it would be substituting its discretion for that of the executive. In other words, the Constitutional Court was concerned that by adjudicating the issues in the petition, it would intrude into the domain of the executive in conflict with the principle of separation of powers.

\footnotetext{
80) Section $111(2)$ provides that "the functions of the Cabinet shall be to determine, formulate and implement the policy of the Government and to perform such other functions as may be conferred by this Constitution or any other law."

81) Sections $176(2)($ e) provides that "appropriate measures shall be taken to enable local government units to plan, initiate and execute policies in respect of all matters affecting the people within their jurisdictions."

82) Citing Attorney General v. Major General David Tinyefuza, Baker v Carr, supra, and Coleman v Miller, 307 U.S. 433 (1939).

83) Andrew Kayira v Edward Rugumayo, Constitutional Case No 1 (1979).
} 
Therefore, the Constitutional Court sustained the government's preliminary objections and held that it had no power to determine or enforce its jurisdiction on matters that required analysis of government health sector policies because the acts or omissions complained of were committed to the political branches and thus fell under the political question doctrine. Professor Wechsler and other commentators characterize this version of application as the classical political question doctrine. ${ }^{84}$ According to Cutaiar, the classical version was recognized in the landmark Supreme Court decision Marbury. ${ }^{85}$ The basic premise of the classical version is that "the political question doctrine is itself a product of constitutional interpretation, rather than of judicial discretion." ${ }^{86}$ I agree with proponents of the classical political question doctrine that the only appropriate use of the political question doctrine is to jurisprudentially guide the court in determining the circumstances the Constitution has committed to another branch of government the determination of a question. ${ }^{87}$

\section{Conclusion}

Based on the above analysis, it is plain that the political question doctrine is an integral part of Uganda's constitutional law. The courts have applied this doctrine to deal with some of the most important constitutional questions in Uganda. A common feature in the application of this doctrine in Uganda is that courts place a particular emphasis on the Constitution's text and the preservation of the separation of powers. ${ }^{88}$ The discussion above demonstrates how Uganda has come to grips with the judicial response to political questions.

\footnotetext{
84) Wechsler, supra note 1 at 9 . Wechsler has been interpreted as stating that the judiciary has no basis, and o business, abstaining to hear a case where the Constitution could fairly be interpreted as requiring them to abstain. See, Gouin, supra note 60 at 778 . See also T. Cutaiar, 'Lane Ex Rel. Lane v Halliburton: The Fifth Circuit's Recent Treatment of the Political Question Doctrine and What It Could Mean for Commer v Murphy Oil', 55 Loyola Law Review (2009), 393-412, at 398. The other political question doctrine version is called the prudential version commonly associated from Professor Bickel. The prudential version is a judge-made overlay that courts have used at their discretion to protect their legitimacy and to avoid conflict with the other political branches. See Barkow, supra note 21 at 253 .

85) Cutaiar, supra note 84 (arguing that the political question doctrine is a product of constitutional interpretation rather than judicial discretion).

86) Scharpf, supra note 62 at 538.

87) Wechsler, supra note 1 at $7-8$.

88) See, Baker v Carr, supra note 12; Ghana Bar Association v Attorney-General [2003-2004] SCGLR 250; Onuoha v Okafor (1983) NSCC 494 (holding that the lack of satisfactory criteria for a judicial determination of a political question is one of the dominant considerations in determining whether a question falls within the category of political questions); and Balarabe Musa v. Auta Hamzat, (1983) 3 NCLR 229, 247 (holding that the impeachment of a State governor was a political question not appropriate for judicial review. Justice Ademola reasoned that "impeachment proceedings are political and for the court to enter into the political thicket as the invitation made to it clearly implies in my view asking its gates and its walls to be painted with mud; and the throne of justice from where its judgments are delivered polished with mire").
} 